\title{
The Effect of Reciprocal Learning Model Assisted by IT Media and Social Skills Towards Student Learning Outcomes
}

\author{
Sri Harmaida Rahayu ${ }^{1}$, Ibnu Hajar ${ }^{2}$, Hidayat ${ }^{3}$ \\ ${ }^{1}$ Postgraduate Student in Universitas Negeri Medan, Indonesia \\ ${ }^{2,3}$ Lecturer in Universitas Negeri Medan, Indonesia \\ sriharmaidarahayu80@gmail.com
}

\begin{abstract}
The aims of this study are: 1) differences in students learning outcomes of Social Sciences Subject taught with Reciprocal learning model assisted by IT media with students learning outcomes of Social Sciences Subject taught with Reciprocal learning model without IT media, 2) Differences in students learning outcomes of Social Sciences Subject who have personal social skills with students learning outcomes of Social Sciences Subject who have peer tutoring social skills, and 3) Interactions between Reciprocal learning model are assisted by IT media and Reciprocal learning model without using IT media with social skills on students learning outcomes of Social Sciences Subject. The research is conducted in Public Elementary School (SDN) 101794 Patumbak which is located in Pertahanan Street, Pasar VII, Patumbak I. The population in this study are $4^{\text {th }}$ grade students in Public Elementary School (SDN) 101794 in the 2016/2017 Academic Year which amounted to 60 students. $4^{\text {th }}$ A grade were 30 students and $4^{\text {th }} B$ were 30 students. Data collection techniques uses in this study are observation techniques with social skills observation sheet instruments, besides that in this study also uses learning outcomes test instruments. Data analysis techniques in this study uses Two Way Anova. The results show that: (1) There are significant differences between students learning outcomes of Social Sciences Subject taught with Reciprocal learning model assisted by IT media with students learning outcomes of Social Sciences Subject taught with Reciprocal learning model without IT media ( $F_{\text {hitung }}=17.064$ and sig. 0.000>0.05); (2) There is a significant difference between students learning outcomes of Social Sciences Subject who have personal social skills with students learning outcomes of Social Sciences Subject who have peer tutoring social skills $\left(F_{\text {hitung }}=10.602\right.$ and sig values. 0.000>0.05); (3) There is an interaction between reciprocal learning model and social skills towards students' learning outcomes of Social Science Subject $\left(F_{\text {hitung }}=22,115\right.$ and sig. 0,000>0,05).
\end{abstract}

Keywords : reciprocal learning model; IT media; social skills; social skills

\section{Introduction}

The first education a child passes and receives is education in the family. Children tend to be whatever is heard, seen, experienced and taught by their parents both knowledge, skills, the formation of behavioral attitudes of everything that is accepted, possibly all that is in the family will continue to be practiced outside their home or social environment (Mardhatillah, 2018).

Social Science Subject teaching in Elementary School is aimed at fostering students to understand their potential and role in their various life systems, live up to the necessity and importance of community with a sense of togetherness and kinship and are adept at acting in their environment as good social beings and citizens. For this reason, Social Science Subject teaching must be able to bring students to the real life facts that they can live. It is hoped that through social studies teaching the attitude of citizens who are sensitive to social problems that help children to recognize human relations with the surrounding environment and social skills through social studies. 
Sjamsuddin and Maryani in (Ahmad Susanto, 2014: 42) social skills is a skill that is capable of being seen in action, able to search, sort and process information, able to learn new things that solve everyday problems, have good oral communication skills and writing, understanding, appreciating and being able to work with other people who are plural, able to transform academic abilities and adapt to the development of global society.

According to Setiana (2014) people who have high social skills are more successful than people who have higher academics. It can be seen if the child has high social skills so he will understand the importance of interacting with peers, interacting with themself and academically. This shows that social skills have a function as a means to obtain a good relationship in interacting with others, so that someone who has good social skills will succeed.

The observational results that researchers conducted in $4^{\text {th }}$ grade students on Social Science Subject at Public Elementary School (SDN) 101794 have several problems with social skills found including children lacking confidence in giving their opinions, not daring to ask questions, children not understanding their attitude towards people who are older than them, when told to the front of the class to show a map of the island of Sumatra they tend not to and only brave children who always appear. Likewise with the learning outcomes of Social Science Subject students in Public Elementary School (SDN) 101794 Patumbak, Deli Serdang is still below the average of 7.00. The average score of Social Science Subject learning outcomes still tends to be unsatisfactory.

From the results of observations at the elementary school researchers found that the learning carried out by the teacher still did not vary in using the right learning model and also the limited learning media to support teaching and learning activities. The teacher's unpreparedness to design and implement better and more interesting learning by applying appropriate and appropriate models, strategies, methods and media can be in the form of teacher inadequacies from the aspect of competence, as well as the teacher's willingness to do so, because the work certainly requires time and skills sufficient. The teacher feels well established by the way he teaches and is reluctant to start renewal. Learning strategies like this students only receive information (knowledge) from what is delivered by the teacher, so that students are less empowered. In other words students gain knowledge because they are "notified" by their teacher and not because they "find themselves" directly by students.

The ideal conditions expected from the results of social studies learning in schools are considered not in line with expectations, because the activities of students in social studies are very necessary because in principle learning is doing. Doing to change behavior by doing activities. Activity is a principle or principle that is very important in teaching and learning interactions both teacher and student activities and also the learning resources that support the implementation of teacher and student activities. However, the reality of student activities when learning takes place is very low, resulting in low learning outcomes of Social Science Subject.

Judging from the research of Arndana, K, Kristiantari, G, M, and Udayana, K, B, I that the application of audio-visual cooperative reciprocal teaching model influenced Social Science Subject learning outcomes in $5^{\text {th }}$ grade of elementary school students, Letkol Wisnu, North Denpasar District. Based on the results of posttest data analysis shows that the average score of reciprocal learning outcomes of social studies students is higher than the average value of science learning outcomes of conventional group students. Based on the description above, a study with the title "The Effect of Reciprocal Learning Model Assisted by IT media is needed. And Social Skills for Student Social Science Subject Learning Outcomes". 


\section{Theoretical Study}

\subsection{Reciprocal Learning Model}

According to Widiya (2011:2) reciprocal is a teaching procedure or approach designed to teach students about cognitive strategies and to help students understand reading well. Whereas according to Efendi (2013: 86); Reciprocal learning is used to help students focus on what is being read and make students understand the reading. According to Trianto (2014: 191) Reciprocal is an approach to teaching students about learning strategies. Reciprocal was developed to help teachers use collaborative learning dialogues to teach reading comprehension independently in class. The use of this approach was chosen for several reasons, among others: (1) is an activity routinely used by readers; (2) increasing understanding and giving readings of opportunities to monitor themselves; and (3) strongly support collaborative dialogue (discussion).

The learning steps according to Shoimin (2014: 156) are: (1) grouping students and group discussions. Students are grouped into several small groups. Grouping students is based on the ability of each student. This is intended so that the ability of each group formed is almost the same. After the group is formed, they are asked to discuss the accepted student worksheet; (2) making questions (Question Generating). Students make questions about the material discussed then deliver in front of the class; (3) present the results of group work. The teacher tells one of the groups to explain the results of their friends in front of the class, while the other groups respond or ask questions about the findings presented; (4) classifying problems (Clarifying). Students are given the opportunity to ask questions about material that is considered difficult by the teacher. The teacher tries to answer by asking questions. In addition, the teacher held a question and answer related to the material being studied to determine the extent of understanding the concept of students; (5) provide practice questions that contain development questions (Predicting). Students get practice questions from the teacher to be done individually. This question contains questions about the development of the material to be discussed. This is so that students can predict what material will be discussed at the next meeting; and (6) conclude the material being studied (Summarizing). Students are asked to conclude the material discussed.

\subsection{The Nature of Learning and Social Science SubjectLearning Outcomes}

Learning activities in schools are the main activities in improving the quality of national education. Through the teaching and learning process it is expected to achieve educational goals in the form of changes in students' behavior. This learning process requires language to enable people to interact and communicate with each other, share experiences, learn from others, and improve their intellectuality (Anzar \& Mardhatillah, 2018).

Furthermore Shah (2010: 87) said that: "Learning is an activity that processes and is a very fundamental element in the implementation of each type and level of education". While according to Winkel (2006: 37) says that: "Learning is a mental or psychological activity that takes place in active interaction with the environment, which results in changes in knowledge, experience, skills, and attitudinal values, those changes are relatively stay long and trace ". According to Hosnan (2014: 7), overall learning outcomes will appear in the form of: (1) rational and critical thinking; use the principles and basics of understanding in answering critical questions, (2) skills, such as writing and exercising (even though they are motoric, those skills require careful coordination of motion and high awareness, (3) observation, namely the 
acceptance process, interpret, and give meaning to stimuli that enter through the objective senses, (4) associative thinking, namely thinking by associating something using memory, (5) appreciation, namely respecting quality works, (6) habits, for example practice many times until you are accustomed to using good and correct language, (7) attitude, which is a relatively sedentary tendency to react in good or bad ways to certain people or goods, and (8) attitude behavior, namely behavior related to fear , angry, sad, happy and so on. Learning is modification or strengthening behavior through experience. According to him, this experience can be get from the interaction between individuals and their environment (Wirdaningsih \& Mardhatillah, 2016)

The success of students in the social studies learning process can also be seen from the results of their learning. Students are said to be successful in the social studies learning process if these students have been able to behave in accordance with the competencies expected from social studies learning both from the cognitive, affective, and psychomotor aspects. From the explanation above, it can be concluded that the results of social studies learning in this study include the ability of students to understand the concept of social studies, understand the interrelationships between concepts and the ability to apply the social concepts of life that students undergo. In other words, social studies learning outcomes are abilities obtained by students after receiving or completing a learning experience that causes changes in behavior in students. Learning outcomes can be measured after following the learning process using relevant tests or instruments.

\subsection{Social Skills}

Sjamsuddin and Maryani in (Ahmad Susanto, 2014: 42) social skills is a skill that is capable of being seen in action, able to search, sort and process information, able to learn new things that solve everyday problems, have good oral communication skills and writing, understanding, appreciating and being able to work with other people who are plural, able to transform academic abilities and adapt to the development of global society.

The characteristics of individuals who have social skills, according to Eisler et al (L'Abate \& Milan, 1985) are: people who dare to speak, give deep consideration, give a faster response, give complete answers, express evidence that can convince others, not give up easily, demand reciprocity, and be more open in expressing themselves. While Philips (L'Abate \& Milan, 1985) states the characteristics of individuals who have social skills include: proactive, prosocial, giving and receiving equally.

The ways to develop social skills for students are as follows: (1) communicate well with others; (2) giving opinions / ideas; (3) active participation in group discussions / activities; (4) listening to others; (5) spontaneously submit and answer other people's questions; (6) lead group discussions; (7) act responsibly, and (8) help others.

\section{Research Methods}

This type of research is a quiz experiment with a $2 \times 2$ factorial design. The research was conducted at Public Elementary School (SDN) 101794 Patumbak which is located at Pertahanan Street, Pasar VII Patumbak I. Population in this study were $4^{\text {th }}$ grade students in Public Elementary School (SDN) 101794, 2016/2017 Academic Year which amounted to 60 students. $4^{\text {th }} \mathrm{A}$ grade were 30 students and $4^{\text {th }} \mathrm{B}$ were 30 students. Data collection techniques which is used in this research is an observation technique with a social skills observation sheet 
instrument, besides that in this study also uses learning outcomes test instruments. Data analysis techniques which is used in this research is inferential statistical techniques. Testing the hypothesis is done by Two Way Anova test with a significant level of 0.05 . Before the Two Way Anova test is carried out, the analysis requirements test was first performed, namely the normality test and the data homogeneity test. The normality test was carried out by the Kolmogorov-Smirnov test while the data homogeneity test was carried out by the Levene test with a significant level of 0.05 .

\subsection{Description of Data}

\section{Research Results and Discussion}

a. Pretest of Student Learning Outcomes

Before doing treatment with reciprocal models assisted by IT media and reciprocal models without using IT media, researchers first conducted a pretest of learning outcomes. The following are the pre test results of the two classes studied.

Table 1 Pretest Results of Learning Outcomes of Students in Experimental Classes and Control Classes

\begin{tabular}{|c|c|c|c|c|c|}
\hline \multicolumn{2}{|c|}{ Experimental Classes } & \multicolumn{3}{c|}{ Control Classes } \\
\hline Interval & $\mathbf{F}$ & Percentage & Interval & F & Percentage \\
\hline $13-21$ & 4 & $13 \%$ & $23-28$ & 7 & $23 \%$ \\
\hline $22-30$ & 6 & $20 \%$ & $29-34$ & 5 & $17 \%$ \\
\hline $31-39$ & 6 & $20 \%$ & $35-40$ & 5 & $17 \%$ \\
\hline $40-48$ & 10 & $33 \%$ & $41-46$ & 5 & $17 \%$ \\
\hline $49-57$ & 2 & $7 \%$ & $47-52$ & 4 & $13 \%$ \\
\hline $58-66$ & 2 & $7 \%$ & $53-58$ & 4 & $13 \%$ \\
\hline Total & $\mathbf{3 0}$ & $\mathbf{1 0 0 \%}$ & & $\mathbf{3 0}$ & $\mathbf{1 0 0 \%}$ \\
\hline
\end{tabular}

Based on Table 1 it can be seen that the pretest data on student learning outcomes in the experimental class and control class. Based on these results it can be concluded that there are differences in the average pretest results of learning obtained by the experimental class and the control class. Furthermore, the frequency distribution table data above can be described in the form of a histogram as in Figure 1 below.

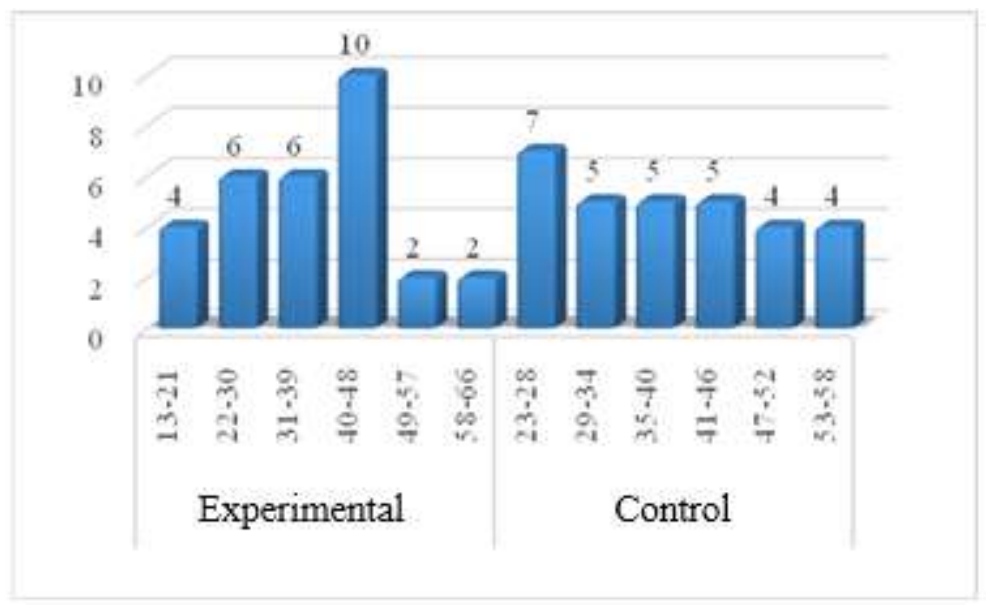

Figure 1 Histogram of Pretest Data Students of Experimental Class and Control Class 
b. Student Learning Results Taught with Reciprocal Models Assisted by IT media

From the data obtained and the results of statistical calculations, it is known that student learning outcomes of Social Sciences subject taught with reciprocal models assisted by IT media get the lowest score of 57, and the highest score is 90, with an average of 78.19; standard deviation of 8.23. The frequency distribution of student learning outcomes of Social Sciences subject taught with reciprocal models assisted by IT media.

Table 2 Frequency Distribution of Student Learning Outcomes

\begin{tabular}{|c|c|c|}
\hline \multicolumn{3}{|c|}{ Experimental Class } \\
\hline Interval & Frequency & Percentage (\%) \\
\hline $57-62$ & 1 & $3 \%$ \\
\hline $63-68$ & 1 & $3 \%$ \\
\hline $69-74$ & 8 & $27 \%$ \\
\hline $75-80$ & 9 & $30 \%$ \\
\hline $81-86$ & 6 & $20 \%$ \\
\hline $87-92$ & 5 & $17 \%$ \\
\hline Total & 30 & $100 \%$ \\
\hline
\end{tabular}

The frequency distribution of students' learning outcomes of Social Sciences Subject scores taught by reciprocal models assisted by IT media is visually shown in the form of the following histogram images:

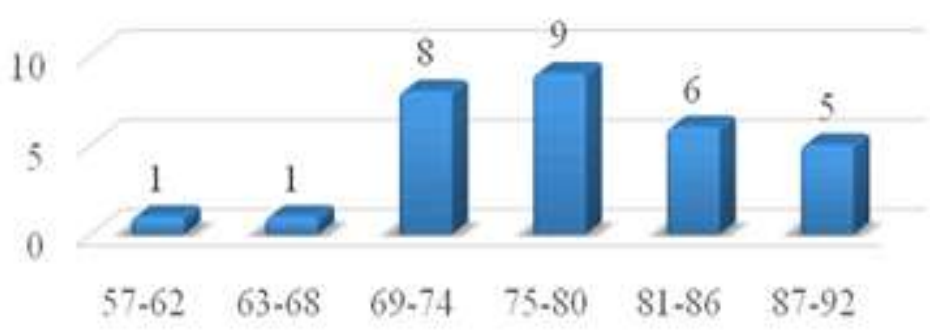

Figure 2 Histogram of Learning Outcomes of Social Sciences Taught with Reciprocal Models Assisted by IT media

c. Learning Outcomes of Students who are Taught with Reciprocal Models without IT Media As

From the data obtained and the results of statistical calculations it is known that students learning outcomes of Social Science Subject of taught with reciprocal models without IT media get the lowest score of 57, and the highest score is 83, with an average of 69.44; variants of 61.99 and standards deviation of 7.87. The frequency distribution of learning outcomes of Social Science Subject taught by reciprocal models without IT media are presented in the following table.

Table 3 Frequency Distribution of Student Learning Outcomes

\begin{tabular}{|c|c|c|}
\hline \multicolumn{3}{|c|}{ Control Class } \\
\hline Interval & Frequency & Percentage (\%) \\
\hline $57-61$ & 6 & $20 \%$ \\
\hline
\end{tabular}




\begin{tabular}{|c|c|c|}
\hline $62-66$ & 3 & $10 \%$ \\
\hline $67-71$ & 9 & $30 \%$ \\
\hline $72-76$ & 2 & $7 \%$ \\
\hline $77-81$ & 9 & $30 \%$ \\
\hline $82-86$ & 1 & $3 \%$ \\
\hline Total & $\mathbf{3 0}$ & $\mathbf{1 0 0 \%}$ \\
\hline
\end{tabular}

Distribution of students' learning outcomes of Social Sciences Subject scores taught by reciprocal models without IT media are shown in the form of the following histogram images:

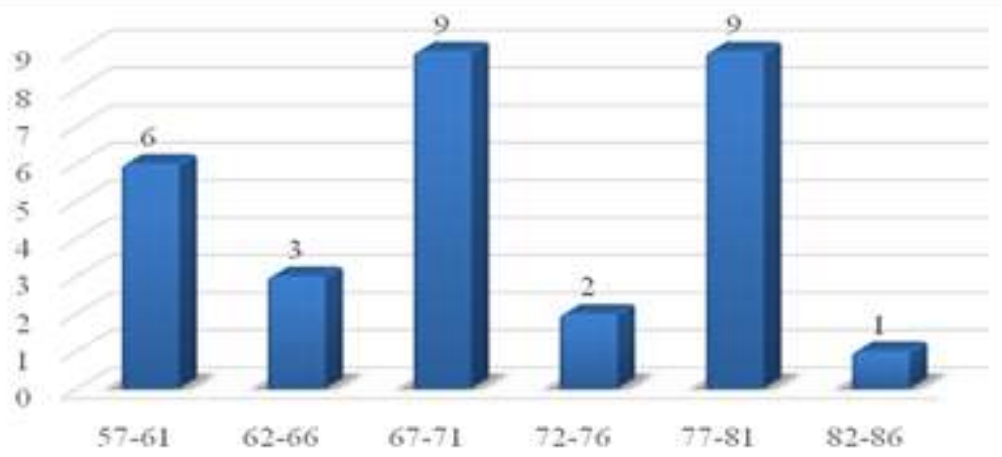

Figure 3 Histograms of Student Learning Outcomes of Social Sciences Subjcet Taught with eciprocal Learning Model IT Media

\subsection{Test Prerequisites}

\section{a. Normality Test}

Tests of Normality

\begin{tabular}{|l|r|r|r|r|r|r|}
\hline & \multicolumn{3}{|c|}{ Kolmogorov-Smirnov $^{\mathrm{a}}$} & \multicolumn{3}{c|}{ Shapiro-Wilk } \\
\cline { 2 - 7 } & Statistic & \multicolumn{1}{c|}{ df } & \multicolumn{1}{c|}{ Sig. } & \multicolumn{1}{c|}{ Statistic } & df & \multicolumn{1}{c|}{ Sig. } \\
\hline $\begin{array}{l}\text { Standardized Residual } \\
\text { for Learning Outcome }\end{array}$ &, 105 & 60 &, 097 &, 980 & 60 &, 434 \\
\hline
\end{tabular}

a. Lilliefors Significance Correction

\section{b. Homogeneity Test}

Levene's Test of Equality of Error Variances ${ }^{a}$

Dependent Variable: Learning Outcomes

\begin{tabular}{|c|c|c|c|c|}
\hline F & & df1 & df2 & Sig. \\
\hline & 1,738 & 3 & 56 & , 170 \\
\hline
\end{tabular}

Based on the table above, It shows that testing of research data homogeneity is obtained by the probability value or sig value. amounting to $0.170>0.05$, thus it can be concluded that the research data group is relatively similar or homogeneous.

\subsection{Hypothesis Test}

Testing the hypothesis of this study using two-way ANOVA with factorial $2 \times 2$, hypothesis testing is calculated with the help of SPSS version 23. Data on hypothesis testing can be seen in the following table: 
Tabel 4 Output SPSS Calculation Two Way Anova

Tests of Between-Subjects Effects

Dependent Variable: Learning Outcomes

\begin{tabular}{|l|r|r|r|r|r|}
\hline \multicolumn{1}{|c|}{ Source } & $\begin{array}{c}\text { Type III Sum } \\
\text { of Squares }\end{array}$ & df & \multicolumn{1}{c|}{$\begin{array}{c}\text { Mean } \\
\text { Square }\end{array}$} & \multicolumn{1}{c|}{ F } & \multicolumn{1}{c|}{ Sig. } \\
\hline Corrected Model & 1756,052 & 3 & 585,351 & 10,546 &, 000 \\
Intercept & 285747,784 & 1 & 285747,784 & 5148,142 &, 000 \\
Model Reciprocal & 947,162 & 1 & 947,162 & 17,064 &, 000 \\
Keterampilan_Sosial & 588,478 & 1 & 588,478 & 10,602 &, 002 \\
Model Reciprocal * & 238,095 & 1 & 1194,667 & 22,115 &, 000 \\
Keterampilan_Sosial & 3108,282 & 56 & 55,505 & & \\
Error & 331946,000 & 60 & & & \\
Total & 4864,333 & 59 & & & \\
Corrected Total & & & & \\
\hline
\end{tabular}

a. R Squared = ,361 (Adjusted R Squared $=, 327)$

\section{First hypothesis:}

$$
\begin{aligned}
& \mathrm{H}_{\mathrm{o}}: \mu \mathrm{A}_{1}=\mu \mathrm{A}_{2} \\
& \mathrm{H}_{\mathrm{a}}: \mu \mathrm{A}_{1} \neq \mu \mathrm{A}_{2}
\end{aligned}
$$

Based on the SPSS output, the ANOVA calculation results in Table 4 shows that the calculated $\mathrm{F}$ value in the reciprocal model is 17.064 and the significant value is 0.000 with $\alpha=$ 0.05 . Then it can be seen that the significant value is $0,000>0.05$ so the hypothesis testing rejects $\mathrm{H}_{\mathrm{o}}$ and accepts $\mathrm{H}_{\mathrm{a}}$. Thus it can be concluded that there is a significant differences between students learning outcomes of Social Sciences Subject taught with Reciprocal learning model assisted by IT media with students learning outcomes of Social Sciences Subject taught with Reciprocal learning model without IT media.

\section{Second hypothesis:}

$$
\begin{aligned}
& \mathrm{H}_{\mathrm{o}}: \mu \mathrm{B}_{1}=\mu \mathrm{B}_{2} \\
& \mathrm{H}_{\mathrm{a}}: \mu \mathrm{B}_{1} \neq \mu \mathrm{B}_{2}
\end{aligned}
$$

Based on the SPSS output, the ANOVA calculation results in Table 4 shows that the calculated F value on social skills is 10.602 and a significant value is 0.000 with $\alpha=0.05$. Then it can be seen that the significant value is $0,000>0.05$ so the hypothesis testing rejects $\mathrm{H}_{\mathrm{o}}$ and accepts $\mathrm{H}_{\mathrm{a}}$. Thus it can be concluded that There are significant difference between students learning outcomes of Social Sciences Subject who have personal social skills with students learning outcomes of Social Sciences Subject who have peer tutoring social skills.

\section{Third hypothesis:}

$$
\begin{aligned}
& \mathrm{H}_{\mathrm{o}}: \mathrm{A} \times \mathrm{B}=0 \\
& \mathrm{H}_{\mathrm{a}}: \mathrm{A} \times \mathrm{B} \neq 0
\end{aligned}
$$

Based on the SPSS output, the ANOVA calculation results in Table 4 show that $F_{\text {hitung }}=22,115$ and a significant value of 0,000 with $\alpha=0,05$. Then it can be seen that the value of sig. $0,000<0,05$ so that the hypothesis testing rejects $\mathrm{H}_{\mathrm{o}}$ and accepts $\mathrm{H}_{\mathrm{a}}$. Thus it can be concluded that There is an interaction between reciprocal learning model and social skills towards students' learning outcomes of Social Science Subject. The results of interaction between reciprocal learning models and social skills in influencing student learning outcomes of Social Sciences subject can be seen in the following figure. 


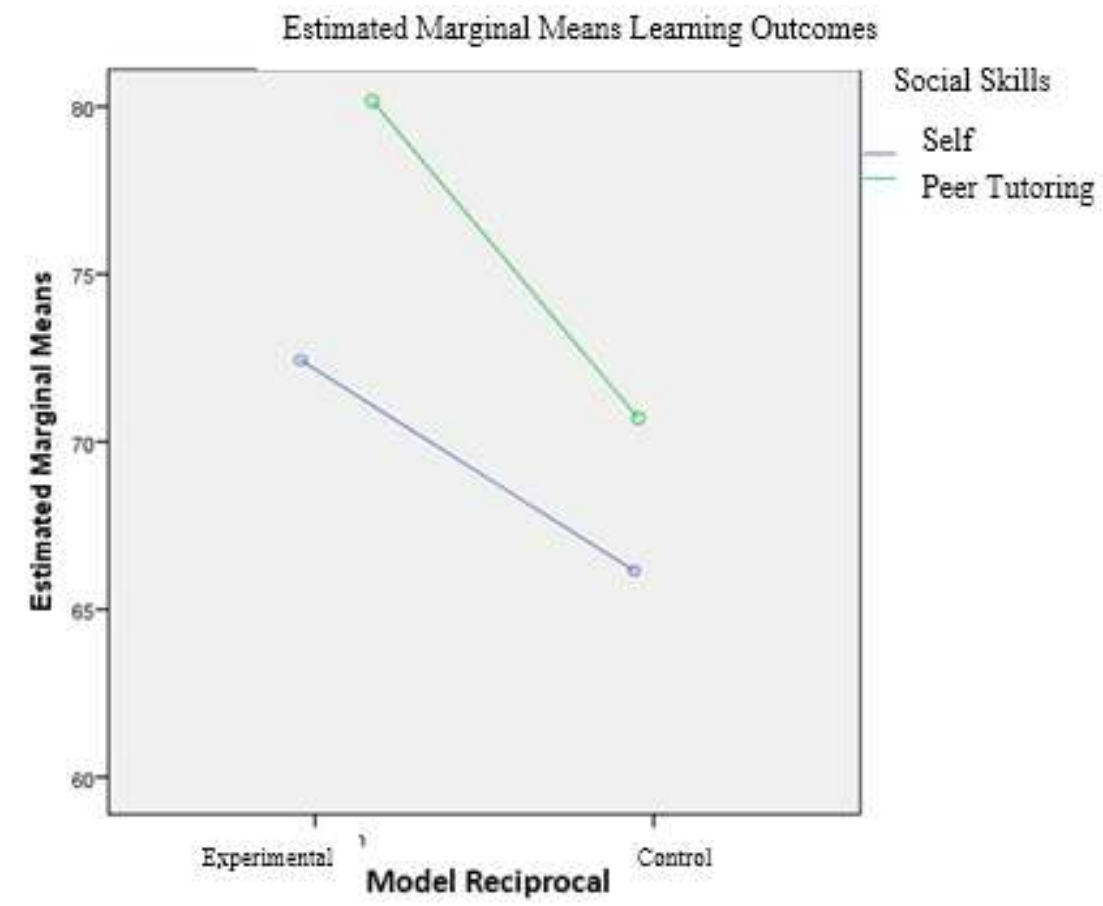

Figure 4 Graph of Interactions between Reciprocal Models and Social Skills in Affecting

\subsection{Tukey Test}

Learning Outcomes

Further testing of the interaction between reciprocal models and students' social skills towards student learning outcomes aims to determine differences in student learning outcomes in each group. After the hypothesis test is carried out, then it is necessary to do further testing using Post Hoc with the Tukey test, the results of which are presented in the following table.

Table 5 SPSS Output of Tukey Test Results

Multiple Comparisons

Dependent Variable: Learning Outcomes

Tukey HSD

\begin{tabular}{|c|c|c|c|c|c|c|}
\hline \multirow[b]{2}{*}{ (I) Group } & \multirow[b]{2}{*}{ (J) Group } & \multirow{2}{*}{$\begin{array}{c}\text { Mean } \\
\text { Difference } \\
\text { (I-J) }\end{array}$} & \multirow[b]{2}{*}{$\begin{array}{l}\text { Std. } \\
\text { Error }\end{array}$} & \multirow[b]{2}{*}{ Sig. } & \multicolumn{2}{|c|}{$\begin{array}{c}95 \% \text { Confidence } \\
\text { Interval }\end{array}$} \\
\hline & & & & & \begin{tabular}{l|} 
Lower \\
Bound
\end{tabular} & $\begin{array}{l}\text { Upper } \\
\text { Bound }\end{array}$ \\
\hline \multirow{3}{*}{$\begin{array}{l}\text { Reciprocal IT- } \\
\text { DS }\end{array}$} & Reciprocal IT-TS & $-5,32$ & 2,968 & 288 & $-13,18$ & 2,54 \\
\hline & Reciprocal tanpa IT-DS & $9,69^{*}$ & 3,285 &, 023 & 1,00 & 18,39 \\
\hline & Reciprocal tanpa IT-TS & 1,78 & 3,042 & ,936 & $-6,28$ & 9,83 \\
\hline \multirow[t]{3}{*}{ Reciprocal IT-TS } & Reciprocal IT-DS & 5,32 & 2,968 & 288 & $-2,54$ & 13,18 \\
\hline & Reciprocal tanpa IT-DS & $15,01^{*}$ & 2,696 &, 000 & 7,87 & 22,15 \\
\hline & Reciprocal tanpa IT-TS & $7,10^{*}$ & 2,393 &, 022 &, 76 & 13,43 \\
\hline \multirow{3}{*}{$\begin{array}{l}\text { Reciprocal } \\
\text { without IT-TS }\end{array}$} & Reciprocal IT-DS & $-9,69^{*}$ & 3,285 &, 023 & $-18,39$ & $-1,00$ \\
\hline & Reciprocal IT-TS & $-15,01^{*}$ & 2,696 &, 000 & $-22,15$ & $-7,87$ \\
\hline & Reciprocal tanpa IT-TS & $-7,92^{*}$ & 2,777 &, 030 & $-15,27$ &,- 56 \\
\hline \multirow{3}{*}{$\begin{array}{l}\text { Reciprocal } \\
\text { without IT-TS }\end{array}$} & Reciprocal IT-DS & $-1,78$ & 3,042 & 936 & $-9,83$ & 6,28 \\
\hline & Reciprocal IT-TS & $-7,10^{*}$ & 2,393 &, 022 & $-13,43$ &,- 76 \\
\hline & Reciprocal tanpa IT-DS & $7,92^{*}$ & 2,777 &, 030 &, 56 & 15,27 \\
\hline
\end{tabular}



follows:

Based on Table 5, an explanation of the Tukey test can be given. The explanation is as

1) Based on the results of the Tukey test it can be concluded that there are significant differences in learning outcomes between groups of students who are taught with reciprocal models assisted by IT media and have personal social skills with students who are taught with reciprocal models without IT media and have personal social skills (Mean Diff = 9.69; sig. $0.023<0.05$ );

2) Based on the results of the Tukey test it can be concluded that there are significant differences in learning outcomes between groups of students taught by reciprocal models assisted by IT media and have social skills peer tutoring with students who are taught with reciprocal models without media assistance and have personal social skills (Mean Diff = 15.01; sig. 0,000<0,05);

3) Based on the results of the Tukey test it can be concluded that there are significant differences in learning outcomes between groups of students taught by reciprocal models assisted by IT media and have social skills peer tutors with students who are taught with reciprocal models without media assistance and have social skills peer tutoring (Mean Diff = 7.10; sig. $0.022<0.05$ );

4) Based on the results of the Tukey test it can be concluded that there are significant differences in learning outcomes between groups of students who are taught with reciprocal models without media assistance and have social skills peer tutoring with students who are taught with reciprocal models without media assistance and have selfsocial skills (Mean Diff $=7.92$; sig. $0.030<0.05$ ).

\subsection{Discussion}

IT media in the learning model can provide more information through the LCD screen. By giving more information to students through the LCD screen, the learning can give students a distinct impression and attract students' attention when learning takes place. In addition to IT media assistance. An explanation of the media was also stated by Mahnun (2012: 28) who said that the media is related to an intermediary that functions to channel messages and information from sources that will be received by the recipient of the message that occurs in the learning process. The use of IT-based learning media will make learning effective and enjoyable (Mardhatillah, 2018)

Based on the results of the research conducted, it was found that the average student learning outcomes taught with reciprocal learning models assisted by IT media were 75.127. Meanwhile, the average student learning outcomes taught with reciprocal learning models without media assistance are 65,736 . Therefore it can be said that in social studies subjects the material about natural resources and economic activities is more precisely taught with reciprocal models assisted by IT media considering that the average learning outcomes obtained by students in this study are higher than the average student learning outcomes. Taught with reciprocal media without media assistance.

The results of the research data analysis through analysis of two-way variance test showed that $F_{\text {hitung }}=17,064$ and significant value is 0,000 with $\alpha=0,05$. Then it can be seen that the significant value is $0,000<0,05$ so that the hypothesis testing rejects $\mathrm{H}_{\mathrm{o}}$ and accepts $\mathrm{H}_{\mathrm{a}}$. Thus it can be concluded that there are significant differences between social studies learning outcomes of students who have personal social skills with learning outcomes of students who have social skills peer tutors. This is evidenced by observations carried out for four weeks, students who have peer tutoring skills are more active in class, often ask questions, 
and are more clever to communicate compared to students who have personal social skills, so that this activity can impact on learning outcomes obtained. By paying attention to table 5 about the comparison of learning outcomes based on social skills, it is found that the average learning outcomes of students who have their own social skills were 69.597 lower than the average learning outcomes of students who had peer tutors social skills of 76.214. In other words the average learning outcomes of students who have peer tutoring skills are higher than the average learning outcomes of students who have personal social skills.

\section{Conclusion}

Based on the results of the research and discussion previously described, some conclusions can be drawn including the following:

1. Learning outcomes of Social Sciences Subject (IPS) students taught with reciprocal models assisted by IT media are higher than the learning outcomes of Social Sciences Subject (IPS) students taught with reciprocal models without media assistance

2. There is a significant difference between the learning outcomes of Social Sciences Subject (IPS) students who have personal social skills with learning outcomes of Social Sciences Subject (IPS) students who have peer tutors social skills $\left(F_{\text {hitung }}=10.602\right.$ and sig. $0,000>0.05$ )

3. There is an interaction between reciprocal learning models and social skills towards student social studies learning outcomes $\left(F_{\text {hitung }}=22,115\right.$ and sig. $\left.0,000>0.05\right)$

\section{References}

Anzar, S. F., \& Mardhatillah, M. (2018). Analisis Kesulitan Belajar Siswa pada Pembelajaran Bahasa Indonesia di Kelas V SD Negeri 20 Meulaboh Kabupaten Aceh Barat Tahun Ajaran 2015/2016. Bina Gogik, 4 (1).

Mardhatillah, M. (2018). Pengembangan Media Pembelajaran Interaktif Berbasis TIK (Teknologi Informasi Dan Komunikasi) Pada Materi Teks Narasi Di Kelas IV SD/MI. Bina Gogik: Jurnal Ilmiah Pendidikan Guru Sekolah Dasar, 2 (2).

Mardhatillah, M., \& Trisdania, E. (2018). Pengembangan Media Pembelajaran Berbasis Macromedia Flash untuk Meningkatkan Kemampuan Membaca Siswa Di Sd Kelas Ii Negeri Paya Peunaga Kecamatan Meureubo. Bina Gogik, 5(1).

Patrick, Nancy J. 2008. Social Skill for Teenagers and Adults with Asperger Syndrome. London. Jessica kingsley Publishers

Robith, H. 2010. "Penerapan Pendekatan Reciprocal Teaching Berbasis Media Pembelajaran Visual Untuk Meningkatkan Hasil Belajar Pada Materi Pokok Cahaya Siswa Kelas VIII - A MTs Negeri Jeketro Tahun Ajaran 2009/2010.Skirpsi Pendidikan.Semarang: Institut Agama Negeri Walisongo.

Shoimin, A. 2014. 68 Model Pembelajaran Inovatif dalam Kurikulum 2013. Yogyakarta: Arruzza Media.

Steedly, Kathlyn M. 2008. Social Skill and Academic Achievement. Journal Evidence for Education, vol III, isssue II

Susanto, Ahmad. 2014. Pengembangan Pembelajaran IPS di Sekolah Dasar. Jakarta. Kencana. 
Widiya, P, K.2011 "Penerapan Model Pembelajaran Reciprocal TeachingUntuk Meningkatkan Hasil Belajar Siswa Pada Pokok Bahasan Segitiga Siswa Kelas Vii-C Smp Negeri 2 Kepanjen”. Disertasi. Malang: Universitas Negeri Malang.

Wirdaningsih, W., \& Mardhatillah, M. (2016). Penerapan Media Audio-Visual Terhadap Keaktifan Pada Materi Hubungan Antara Sumber Daya Alam Dengan Lingkungan Siswa Kelas IV SD Negeri Pasi Teungoh Kecamatan Kaway XVI. Bina Gogik, 3 (2). 